\title{
研究課題別評価書
}

1. 研究課題名

機能性芳香族フォルダマーの構築と動的立体制御

2. 氏名

棚谷 綾

\section{3. 研究のねらい}

機能性分子の創製にはその立体構造や動的立体挙動を制御した分子設計が必須である。本 研究者らは「芳香族二級アニリド類がトランス型で存在するのに対し、N-メチル化して得られる三 級アミド基が結晶中及び溶液中においてシス型を優先すること」を見いだした。また、N-メチル化 に伴うシス型優先性は、ウレア、アミジン、グアニジン類にも適応可能である一般的な性質である ことを示してきた。本研究では、この立体特性を基盤として、芳香族多層構造やらせん構造などの 芳香族フオルダマ一類の構築とその動的立体挙動制御を行うことにより、機能性芳香族分子開発 の基盤を構築することを目的とする。

\section{4. 研究成果}

本研究では、シス型アミド、ウレア結合の立体特性を基盤として、芳香族多層構造やらせん構 造、環状化合物といったユニークな構造を持つ芳香族分子の構築を行った。これらの芳香族フォ ルダマー分子の溶液中で動的挙動の解析、制御を行った。また、環境に応答して立体構造を変 化させる分子の開発を行い、蛍光センサーとしての有用性を示した。

\section{1) 芳香族層状ウレア分子のらせん構造とその動的立体挙動解析}

$5 \mathrm{MU}$ (Fig. 1)のように (cis, cis) 型構造をとるN,N’ジメチルウレア結合をリンカーとして複数のベ ンゼン環をメ夕位で連結した化合物はすべての軸不斉がそろったらせん状の芳香族多層分子とな る。この分子は結晶中だけでなく、溶液中においてもらせん構造で存在していると考えられるが、 両エナンチオマー間の変換が速く、それらを識別することはできない。本研究では、らせん構造の 動的挙動を解析する目的で、光学活性な置換基を導入した5MU誘導体を合成し、そのUV/CDス ペクトルを詳細に解析した。特に、光学活性なTEG側鎖を導入した化合物1ではCDスペクトルで強 いコットン効果が観測された。5MUの結晶構造を元にしたUV/CDスペクトルの理論計算により、S 配置の側鎖を持つ化合物 1 が骨格の軸不斉がall-R体である構造を優先していることを同定した。

また、IR/VCDスペクトルの実験的及び計算化学的な考察より、同一の結論を得、比較的分子 量の小さな有機化合物の絶対構造を、VCDを用いて決定しうることを示した。 


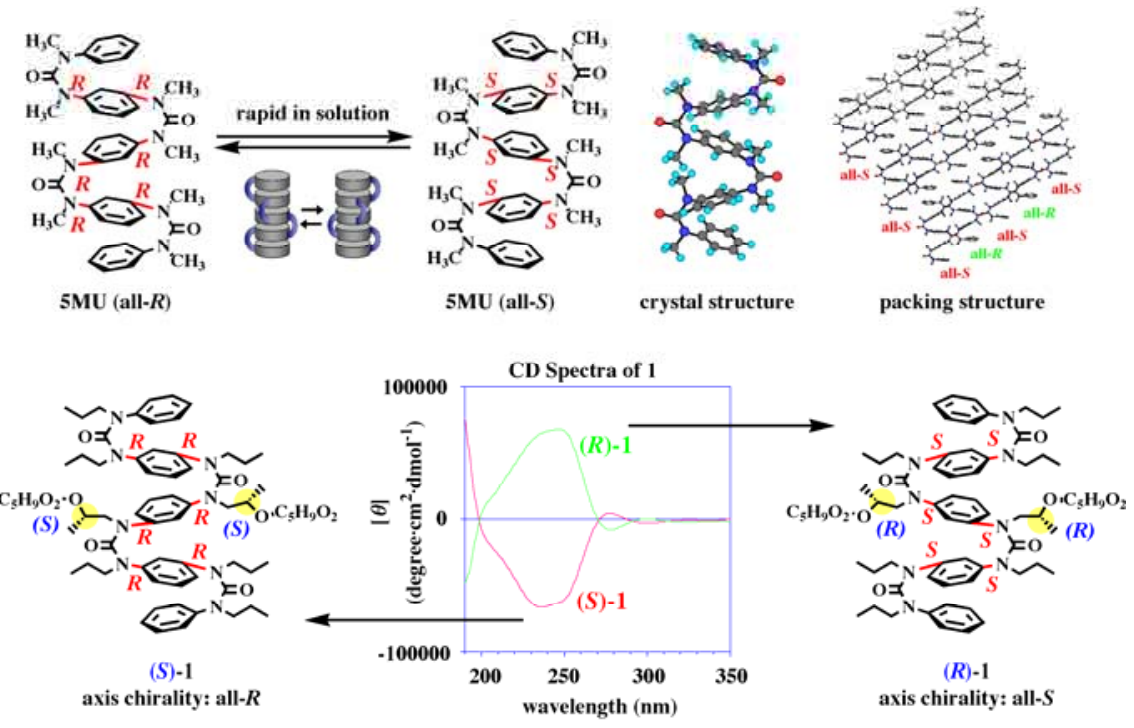

Fig. 1. Dynamic Helical Structure of Aromatic Layered Ureas and the Determination of Absolute Strucutres

2)環状トリアミドの立体特性と動的制御

$m$-(メチルアミノ)安息香酸の縮合反応により得られる環状トリアミド2は、結晶中で3つの芳香環 が同一方向を向いたsyn型構造で存在する(Fig. 2)。この構造は小さなキャビティーを持ち、また、 アミドの方向性による分子不斉を持つ。溶液中では、1つのベンゼン環が反転したanti型との平衡 にある。本研究では、環状構造の立体構造の制御と分子不斉の特性を明らかとした。まず、種々 の置換基を持つ環状トリアミドの合成法を確立し、その立体構造を解析したところ、DMFやメタノー ルなどの極性溶媒中では環状トリアミドがsyn型構造に偏ることをみいだした。また、カルボキシル 基をもつ化合物 3 では、 $\mathrm{CD}_{2} \mathrm{Cl}_{2}$ 中でもsyn型構造しか観測されないが、結晶構造の解析から、カプ セル型の二量体構造をとることを明らかとした。

更に、環状トリアミド 3 の結晶化を詳細に吟味したところ、再結晶溶媒に依存して種々の結晶多 形(擬似結晶多形を含む)を与えることがわかり、環境に応じて二量体構造や連鎖構造をとること を示した(Fig. 2)。 


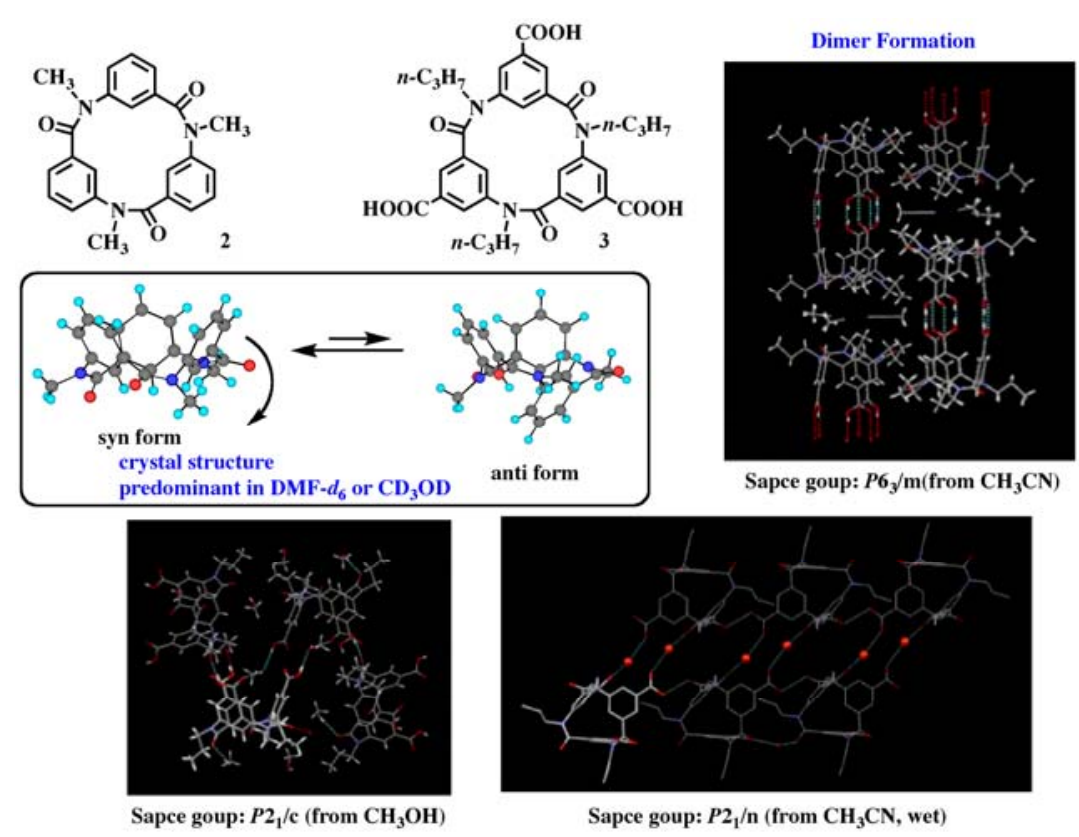

Fig. 2. Cyclic Triamides with A Chiral Cavity: Conformational Properties,

Dimer Formation, and Solvent-dependent Polymorphism

3)環境応答型アミドの創製と蛍光センサーへの応用

N-メチルアセトアニリドの芳香環上の置換基は、cis/transの比率に影響を与え、この性質を利 用して芳香環上置換基のプロトン化により、立体転換するアミド分子を創製してきた。本研究では、 酸化還元反応による立体転換分子4を構築した(Fig. 3)。この系では、電子密度の高いヒドロキノ ン環を酸化して得られるp-キノン環がフェニル基よりも相対的に電子密度が低くなり、立体転換が 起こる。両者は合成化学的及び電気化学的に化学変換が可能であり、Redox依存的な分子スイッ チ機能へと応用できると考えている。

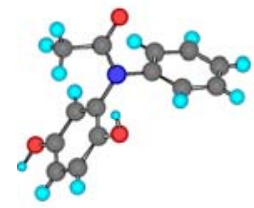

crystal structure

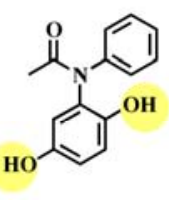

$4 a$

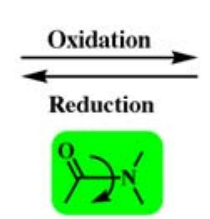

Fig. 3. Redox-dependent Conformational Alteration of Aromatic Amide

また、芳香族アミドの窒素原子上にヒドロキシル基をもつヒドロキサム酸誘導体5が溶媒依存的 にアミド結合の立体が変化することを見いだした(Fig. 4)。本立体転換の根源は不明であるが、再 結晶溶媒により異なる結晶(キラルな結晶も含む)を得ることができ、結晶中では再結晶溶媒中の 主コンフォマーに対応した構造を含んでいた。これまでコンフォメーションの違いによる結晶多形も 
種々知られているが、その多くはコンフオマ一間の変換のエネルギ一障壁が小さく、化合物 5 のよ うに両コンフォマーが溶液中で比較的遅い平衡にあり、その平衡が溶媒及び結晶化によって制御 できる例として興味深い。

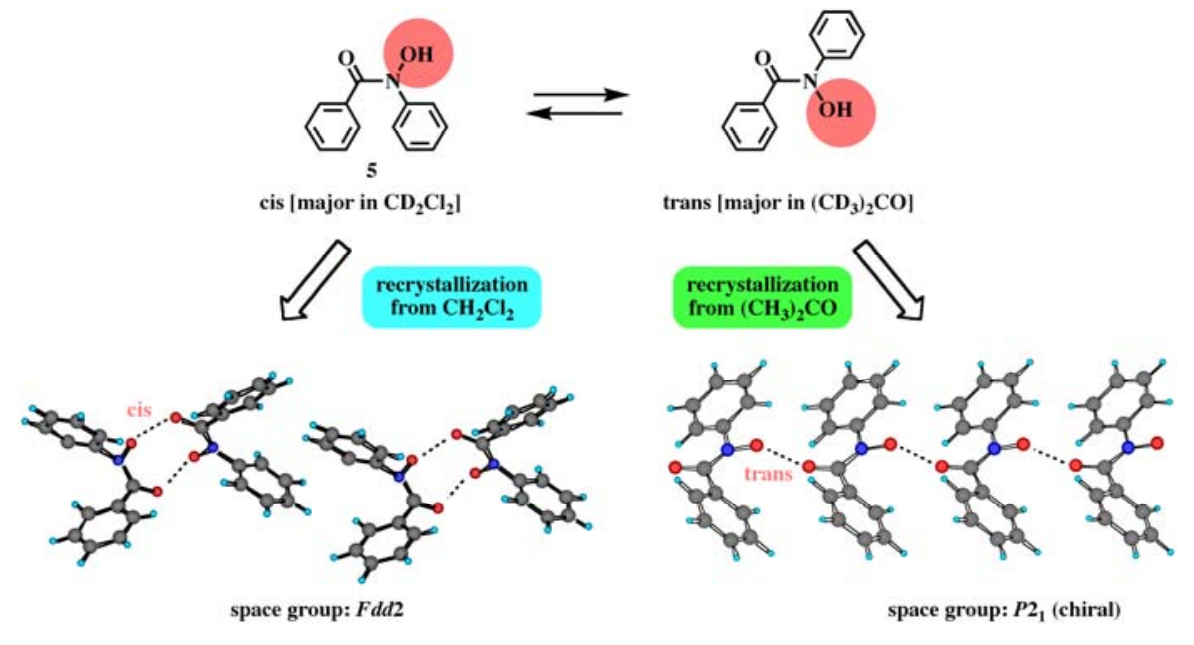

Fig. 4. Solvent-dependent Conformational Change of Hydroxamic Acid

更に、アミド結合やウレア結合の立体変化を蛍光の変化によって可視化することを目的に、化 合物6ー9を合成した。このうち、シス型構造をとる化合物にのみパイレンのエキシマー発光が観 測された。本系はメチル化という化学修飾による立体構造変化の可視化であるが、上記のような 環境応答型アミド分子と組み合わせることで環境応答性蛍光センサーの認識部位として利用しう る。

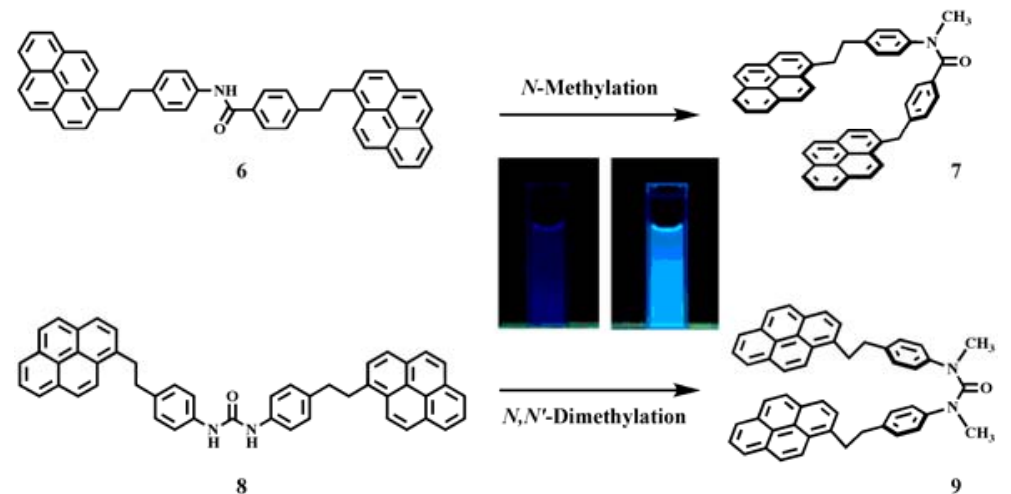

Fig. 5. Fluorescent visualization of Conformational Change of Aromatic Amides and Ureas

\section{5. 自己評価}

本研究の当初目的は、申請者らが見いだした芳香族アミド、ウレア類の立体特性を活かし、疎 水性及び水溶性の各種芳香族フオルダマ一を創製し、その立体構造、動的挙動の解明とそれを 制御することにある。多層構造、らせん分子、環状分子の各種誘導体の合成法の確立、分光学と その理論的解析による、絶対構造含む立体構造の同定と、不斉誘導などの立体構造制御に成功 した。また、環境応答性分子の拡張や、立体構造変化の可視化は、アミド類の動的立体挙動の、 分子スイッチ、蛍光センサ一等への応用性を示している。基礎研究に関しては当初の目的を達成 
していると考えている。一方で、これらの基礎研究をもとに応用研究(機能化)を進めるべく、ポリ マーやポルフィリン誘導体の創製を行ったが、これらの合成法の確立から立ち上げ、試行錯誤し たために、現状では、機能の追究には至っていない。この3年間で、各種誘導体の合成法、ポル フィリンについては詳細な構造情報を蓄積しており、その手法と知見をもとに、機能性芳香族分子 の開発、分子デバイス創製へと展開できると考えている。

\section{6. 研究総括の見解}

芳香族二級アニリド類がトランス型で存在するのに対し、N-メチル化して得られる三級アミド基 が結晶中及び溶液中においてシス型を優先する特異な立体特性を基盤として、芳香族多層構造 やらせん構造などの芳香族フオルダマ一類の構築とその動的立体挙動制御を行うことにより、機 能性芳香族分子開発の基盤を構築することを目的とする研究である。多層構造、らせん分子、環 状分子の各種誘導体の合成法の確立、分光学とその理論的解析による、絶対構造含む立体構 造の同定と、不斉誘導などの立体構造制御に成功し、また、環境応答性分子の拡張や、立体構 造変化の可視化は、その応用性を示唆しているが、さらに新しい構想による分子設計への展開を 期待する。

\section{7. 研究成果リスト}

(1) 論文 (原著論文) 発表

1) Yamasaki, R.; Tanatani, A.; Azumaya, I.; Masu, H.; Yamaguchi, K.; Kagechika, H. Solvent-dependent Conformational Switching of N-Phenylhydroxamic Acid and Its Application in Crystal Engineering. Crystal Growth Des. 6, 2007-2010, 2006.

2) Okamoto, I.; Yamasaki, R.; Sawamura, M.; Kato, T.; Nagayama, N.; Takeya, T.; Tamura, O.; Masu, H.; Azumaya, I.; Yamaguchi, K.; Kagechika, H.; Tanatani, A. Redox-Induced Conformational Alteration of N, N-Diaryamides. Org. Lett. 9, 5545-5547, 2007.

3) Hirano, T.; Osaki, T.; Fujii, S.; Komatsu, D.; Azumaya, I.; Tanatani, A.; Kagechika, H. Fluorescent visualization of the conformational change of aromatic amide or urea induced by $\mathrm{N}$-methylation. Tetrahedron Lett. 50, 488-491, 2009.

4) Mikami, K.; Tanatani, A.; Yokoyama, A.; Yokozawa, T. Helical Folding of Poly(naphthalenecarboxamide) Prompted by Solvophobic Effect. Macromolecules 42, 3849-3851, 2009.

5) Kudo, M.; Hanashima, T.; Muranaka, A.; Sato, H.; Uchiyama, M.; Azumaya, I.; Hirano, T.; Kagechika, H.; Tanatani, A. Identification of Absolute Helical Structures of Aromatic Multilayered Oligo( $m$-phenylurea)s in Solution. J. Org. Chem. 74, 8154-8163, 2009.

(2) 受賞

1) Tetrahedron Letters Most Cited Paper 2004-2007 Award, Development of bis-thiourea-type organocatalyst for asymmetric Baylis-Hillman reaction, Elsevier, July 2007.

(3) 著書·総説

1）棚谷 綾、影近弘之「有機化合物でつくる機能性らせん分子」化学と教育（55）, 406-409, 2007. 
2) Okamoto, I.; Kagechika, H.; Tanatani, A. External Stimulus-Responsive Control of Aromatic Amide Conformations. J. Synth. Org. Chem., Jpn 67, 1240-1249, 2009.

3）棚谷 綾、影近弘之「フォルダマー」、in「超分子サイエンス＆テクノロジー」(監修: 国武豊 喜)、第3章第1節, 467-476, 2009.

(4) 招待講演

1）棚谷 綾「アミドの立体特性を利用した芳香族機能性分子の構築」大阪大学産業科学研究 所 21 世紀COEプログラムセミナ一、大阪大学産業科学研究所、2007 年 1 月 16-17 日.

2）棚谷 綾「芳香族アミドの立体特性を利用した機能性分子の構築」機能性分子ミニシンポジ ウム、筑波大学、2008 年 9 月 13 日

3）棚谷 綾「機能性芳香族分子の化学: 動的立体挙動と機能発現」第1回有機立体化学研究 会講演会、徳島文理大学、2008 年 12 月 20 日

4）棚谷 綾「芳香族アミド分子の立体構造制御と機能」階層横断生命科学シンポジウム、理 化学研究所、2009 年 8 月 7-8 日

(5) 学会発表

(国際学会)

1) Tanatani, A.; Okamoto, I.; Yamasaki, R.; Azumaya, I.; Yamaguchi, K.; Kagechika, H., Conformational Switching of Aromatic Amides. $12^{\text {th }}$ International Symposium on Novel Aromatic Compounds, Awaji Island, Japan, July 22-27, 2007.

2) Tanatani, A.; Kudo, M.; Hanashima, T.; Muranaka, A.; Sato, H.; Uchiyama, M.; Azumaya, I.; Kagechika, H. Helical Structure of Aromatic Multi-layered Oligo( $m$-phenylurea)s. ISNA13, Luxemburg, July 19-24, 2009.

3) Kagechika, H.; Matsumura, M.; Fujimoto, N.; Komatsu, D.; Masu, H.; Katagiri, K.; Azumaya, I.; Tanatani, A. Cyclic Tri( $m-N$-methylbenzamide): Synthesis and Unique syn Conformation Bearing A Chiral Cavity. ISNA13, Luxemburg, July 19-24, 2009.

4) Fujii, S.; Kano, A.; Sekine, R.; Kawachi, E.; Masuno, H.; Hirano, M.; Tanatani, A.; Kagechika, H. Development of Novel Non-secosteroidal Vitamin D Receptor Ligands Based on Carborane as A Hydrophobic Core Structure. $14^{\text {th }}$ Vitamin D Workshop, Brugge, Belgium, Oct. 4-8, 2009.

(国内学会)

1）棚谷 綾、山崎龍、東屋功、桝飛雄真、山口健太郎、影近弘之「溶媒依存的に立体 転 換を引き起こす芳香族アミド誘導体」第32回反応と合成の進歩シンポジウム、広島、 2006 年 12 月 $4-5$ 日

2）棚谷 綾、花島貴幸、村中厚哉、内山真伸、東屋功、影近弘之「芳香族層状ウレアのら せん構造」Symposium on Molecular Chirality 2008、岡山、2008 年 5 月 22-23 日

3）松村実生、村中厚哉、内山真伸、桝飛雄真、東屋功、影近弘之、棚谷 綾「アミドの 立 体特性を活かした機能性ポルフィリン誘導体の創製」第 19 回基礎有機化学討論会、大 阪、2008 年 10 月 3-5 日

4）松村実生、棚谷 綾、藤本慎子、小松大輔、桝飛雄真、片桐幸輔、東屋功、影近弘之 「芳香族環状トリアミド誘導体の立体特性と分子不斉」第 20 回基礎有機化学討論会、 群馬大学工学部、2009 年 9 月 28-30日

5）工藤まゆみ、棚谷 綾、花島貴幸、影近弘之、佐藤久子、村中厚哉、内山真伸「らせん 構造をもつ芳香族多層構造ウレアの創製と動的立体挙動の解明」第 35 回反応と合成の 進歩シンポジウム、金沢、2009 年 11 月 16-17 日 